\title{
PENATAGUNAAN TANAH BERBASIS MASYARAKAT DALAM MENUNJANG SISTEM DAN USAHA AGRIBISNIS DI INDONESIA
}

\author{
R. Kunto Adi \\ Staf Pengajar Program Studi Agribisnis Fakultas Pertanian Universitas Sebelas Maret \\ E-mail: kuntouns@gmail.com
}

\begin{abstract}
Development of agricultural sector, especially for agribusiness sector that problems by large of conversion of agricultural land to used for non agricultural, that cause acess farmers toward agrarian resources, especially limited of land. Except that, factors of the lack of land ownership and authority, threatened of farmers existance on to become cause of agrarian conflict in rural area that more and more glow. The problem of agrarian conflict trigger by more and more increased of developmnet activity. This condition will have consequence to occur conflict in utilizing of land. Except that, too much land resources that carry on not yet or to use appropriate with allocation, to much of occur land utilizing that not appropriate with phisically potency of land and appropriate with land use planning of region. Because of that be needed maked grow about important of land utilizing in a plan manner, in order that used optimally, harmonious, balanced, dan sustainable. Because of that be needed efforts land use planning managemet. Land use planning must be done with participating of community (farmers) in decision making of development policy in order that used integrative, so effort in land use planning process, from a planning, implementation, and supervision. In implementation this programme, land use planning must be with community management approach, for actualization of community capacity and potency or community empowering approach. Programme that become form land use planning management with character of bottom up approach and used to blue print that not to character of dependency creating, until programme that become from land use planning management basic to community must be character of empowering, with the result that community especially farmers not only as object, but like subject, especially for implementation of land use planning process in agribusiness system and business.
\end{abstract}

Keywords: land use planning, community, agribusiness system and business

Abstrak: Pengembangan sektor pertanian, terutama sektor agribisnis, terkendala oleh
banyaknya alih fungsi lahan pertanian ke penggunaan non pertanian, yang
mengakibatkan akses petani terhadap sumber daya agraria, terutama tanah, menjadi
sangat terbatas. Selain itu faktor kesenjangan penguasaan dan kepemilikan tanah dan
terancamnya eksistensi diri para petani pada gilirannya menjadi penyebab utama
terjadinya konflik pertanahan di pedesaan yang kian marak. Masalah pertanahan
dipicu oleh semakin meningkatnya kegiatan pembangunan. Hal ini akan berakibat
pada terjadinya persaingan dalam penggunaan tanah. Dilain pihak, banyak tanah-tanah
yang belum diusahakan atau dimanfaatkan sesuai dengan peruntukkannya, dan
sebaliknya, banyak terjadi penggunaan tanah yang tidak sesuai dengan potensi fisik
tanah dan arahan yang telah digariskan dalam rencana tata ruangnya. Untuk itu perlu
ditumbuhkan tentang arti penting penggunaan tanah secara terencana, agar diperoleh
manfaat yang optimal, serasi, seimbang dan lestari. Oleh karena itu perlu upaya
pengelolaan tata guna tanah atau Penatagunaan Tanah. Penatagunaan tanah harus
dilaksanakan dengan melibatkan masyarakat (petani) dalam pengambilan kebijakan
pembangunan secara integratif, termasuk juga dalam proses penatagunaan tanah, dari 


\section{R. Kunto Adi : Penatagunaan tanah berbasis masyarakat dalam menunjang ...}

mulai perencanaan, pelaksanaan dan pengawasan. Dalam implementasinya, proses penatagunaan tanah harus dengan pendekatan community management untuk mengaktualisasikan potensi masyarakat (empowering). Program-program yang lahir dari manajemen penatagunaan tanah bersifat bottom up dan blue print yang tidak bersifat dependency creating, sehingga program yang lahir dari manajemen penatagunaan tanah berbasis masyarakat cenderung bersifat empowering, sehingga masyarakat terutama petani tidak hanya sebagai obyek, tetapi sebagai subyek, dalam implementasi proses penatagunaan tanah dalam sistem dan usaha agribisnis di Indonesia.

Kata kunci: penatagunaan tanah, masyarakat, sistem dan usaha agribisnis

\section{PENDAHULUAN}

Pembangunan ekonomi ditinjau dari hubungan basis perekonomian antara sektor industri dan jasa di wilayah perkotaan dan sektor pertanian di wilayah pedesaan, maka proses pembangunan telah sejak lama menciptakan disparitas yang semakin tajam, yang dicirikan dengan pesatnya perkembangan sektor perekonomian moderen. Sedangkan sektor ekonomi tradisional yaitu pertanian, yang merupakan basis kehidupan sebagian besar penduduk di Indonesia, praktis mengalami stagnasi yang berkepanjangan. Dualisme pembangunan ini timbul karena tekanan mekanisme pasar serta lemahnya sistem perencanaan wilayah. Perencanaan sangat bias terhadap pembangunan sektor moderen tercermin dari kebijaksanaan pemerintah untuk mendorong modernisasi dan industrialisasi di wilayah perkotaan, yang sekarang sudah merambah di wilayah pedesaan. Dampaknya adalah kondisi perekonomian yang sangat timpang karena sumber daya yang bernilai ekonomis dan berkualitas tinggi yaitu sumber daya manusia, teknologi dan barang-barang komoditas lain mengalir sebagian besar ke wilayah perkotaan, sehingga semakin mendorong pertumbuhan perekonomian sekaligus menenggelamkan wilayah pedesaan termasuk sektor pertanian. Disamping itu, adanya kompetisi tidak seimbang antara sektor ekonomi di wilayah pedesaan dan perkotaan, berakibat pada terjadinya percepatan peralihan fungsi tanah dari sektor ekonomi pedesaan (pertanian) menjadi sektor ekonomi perkotaan (industri, jasa, perumahan, dan lain-lain) atau terjadi penyusutan lahan-lahan pertanian subur beralih fungsi penggunaan sektor non pertanian. Hal tersebut menjadi hambatan utama dalam pengembangan sektor pertanian, terutama sektor agribisnis, terutama di Pulau Jawa, yang sampai saat ini masih menjadi andalan untuk swasembada pangan (Anonim, 1999b). Berdasarkan data dari BPN (Badan Pertanahan Nasional) Republik Indonesia, pada tahun 2009 menunjukkan bahwa alih fungsi lahan pertanian ke penggunaan non pertanian sebesar 110.000 hektar per tahun. Hal tersebut mengakibatkan askes petani terhadap sumber daya agraria, terutama tanah, menjadi sangat terbatas.

Alih fungsi lahan pertanian juga terkait dengan penguasaan tanah untuk kepentingan penanaman modal, yang sudah dijelaskan dalam Pasal 2 Keputusan Menteri Negara Agraria/Kepala BPN No. 21 tahun 1994 bahwa perolehan tanah oleh perusahaan hanya boleh dilaksanakan di areal yang telah ditetapkan di dalam ijin lokasi, yang salah satunya adalah diupayakan areal untuk kawasan industri tidak mengurangi luas lahan pertanian produktif, serta dalam proses perolehan tanah tersebut harus dilaksanakan secara langsung berdasar kesepakatan antara perusahaan dengan pemilik atau pemegang hak atas tanah (Anonim, 2000). Akan tetapi dalam implementasinya, masih banyak pelanggaran terhadap peraturan tersebut, terutama pelanggaran perusahaan terhadap syarat-syarat ijin lokasi dan ketidakadilan dalam perjanjian perolehan dan penggunaan tanah.

Hal tersebut diatas secara langsung dan tidak langsung telah menyebabkan petani semakin banyak kehilangan tanahnya. Berdasarkan data Komite Pembaruan Agraria (KPA) tahun 2002, menunjukkan bahwa paling tidak ada $25 \%$ petani memiliki $74,8 \%$ lahan dengan luas 1-5 hektar, sebanyak $75 \%$ sisanya hanya menguasai $25,8 \%$ lahan dengan luas 0,1 0,99 hektar. Data KPA tersebut selain mengindikasikan bagaimana para petani di 


\section{R. Kunto Adi : Penatagunaan tanah berbasis masyarakat dalam menunjang ...}

pedesaan harus berjuang menyambung hidup pada lahan pertanian yang semakin terbatas atau menyempit, juga memperlihatkan bagaimana para petani mempertaruhkan eksistensinya sebagai petani. Faktor kesenjangan penguasaan dan kepemilikan tanah dan terancamnya eksistensi diri para petani pada gilirannya menjadi penyebab utama terjadinya konflik pertanahan di pedesaan yang kian marak. Data KPA tahun 2002, menunjukkan sebanyak 1.679 konflik pertanahan yang sifatnya struktural dan sebanyak 227.316 KK menjadi korban (Mustain, 2007).

Berbagai hasil penelitian menunjukkan bahwa pada tingkat petani proses fragmentasi lahan karena konversi lahan dari penggunaan untuk pertanian ke penggunaan non pertanian, dan proses pewarisan menyebabkan penguasaan lahan semakin sempit. Hasil penelitian Kustiawan dalam Jamal (2000), selama tahun 1983-1993 di Pantai Utara Jawa, rata-rata luas lahan yang dikuasai rumah tangga petani menurun dari rata-rata 0,58 hektar menjadi 0,47 hektar. Sejalan dengan proses fragmentasi tersebut jumlah petani gurem meningkat dalam kurun waktu yang sama dengan laju 10,41 persen. Sementara itu berdasarkan hasil penelitian Winoto dkk dalam Jamal (2000), menunjukkan bahwa skala pemilikan lahan berpengaruh nyata terhadap alih fungsi lahan, kabupaten dengan rumah tangga tani berskala lebih kecil 0,5 hektar dominan, laju alih fungsi lahan sawahnya cenderung lebih cepat.

Kondisi tersebut menyebabkan sektor pertanian harus menanggung beban berat terkait semakin berkurangnya lahan pertanian produktif, terutama di Pulau Jawa, karena alih fungsi lahan pertanian ke penggunaan non pertanian yang tidak diimbangi oleh kegiatan pencetakan areal pertanian baru, baik dari segi luasan ataupun kualitas lahan. Sementara itu juga pola pewarisan dalam masyarakat cenderung makin mendorong fragmentasi lahan, sehingga rata-rata penguasaan lahan oleh petani terus menurun dari waktu ke waktu. Dampak perubahan penggunaan lahan pertanian menjadi non pertanian, yaitu terkonsentrasinya pembangunan perumahan dan industri, terutama di Pulau Jawa, di satu sisi menambah terbukanya lapangan kerja di sektor non pertanian seperti jasa konstruksi, dan industri, akan tetapi juga menimbulkan dampak negatif yang kurang menguntungkan, antara lain :

1. Luas sawah yang mengakibatkan turunnya produksi padi, yang mengganggu tercapainya swasembada pangan.

2. Berkurangnya luas sawah yang mengakibatkan bergesernya lapangan kerja dari sektor pertanian ke nonpertanian, yang apabila tenaga kerja lokal yang ada tidak terserap seluruhnya justru akan meningkatkan angka pengangguran. Dampak sosial ini akan berkembang dengan meningkatnya kecemburuan sosial masyarakat setempat terhadap pendatang yang pada gilirannya berpotensi meningkatkan konflik sosial.

3. Investasi pemerintah dalam pengadaan prasarana dan sarana pengairan menjadi tidak optimal pemanfaatannya.

4. Kegagalan investor dalam melaksanakan pembangunan perumahan maupun industri, sebagai dampak krisis ekonomi, atau karena kesalahan perhitungan mengakibatkan tidak termanfaatkannya tanah yang telah diperoleh, sehingga meningkatkan luas tanah tidur yang pada gilirannya juga menimbulkan konflik sosial seperti penjarahan tanah.

5. Berkurangnya ekosistem sawah terutama di jalur pantai utara Pulau Jawa yang konon terbaik dan telah terbentuk puluhan tahun, sedangkan pencetakan sawah baru yang sangat besar biayanya di luar Pulau Jawa, tidak memuaskan hasilnya.

(Widjanarko, et al, 2012).

Berbagai masalah pertanahan sebagaimana diuraikan diatas, menunjukkan bahwa percepatan pertumbuhan ekonomi yang diikuti dengan pengupayaan sebesar-besarnya mobilisasi arus investasi dan penanaman modal, baik dalam dan luar negeri, pada gilirannya memerlukan terobosan-terobosan dengan cara memberikan kesempatan dan kemudahan-kemudahan yang sebesar-besarnya melalui paket-paket deregulasi, yang ternyata kemudian disadari bahwa kebijaksanaan pertumbuhan ekonomi dan penanaman modal yang sebesar-besarnya ini, di bidang 


\section{R. Kunto Adi : Penatagunaan tanah berbasis masyarakat dalam menunjang ...}

pertanahan belum sepenuhnya ditunjang dan diimbangi dengan keberpihakan terhadap masyarakat. Oleh karena itu, dalam era reformasi ini perlu kebijakan dan langkahlangkah guna mencegah merebaknya pemilikan dan penguasaan tanah yang kurang bertumpu kepada kepentingan rakyat banyak (Anonim, 1999a).

Sebenarnya dengan menelaah dan mengkaji ulang Undang-undang Pokok Agraria (UUPA) No. 5 tahun 1960, ketimpangan di bidang pertanahan terhadap tuntutan pembangunan melalui peningkatan pertumbuhan ekonomi diatas tidaklah akan terjadi apabila jiwa dan semangat yang terkandung di dalam UUPA tersebut diimplementasikan sebenar-benarnya. UUPA bukan saja berjiwa dan bernuansa kerakyatan, tetapi juga telah memberikan arah bagi pemenuhan kebutuhan dasar (basic needs) penduduk akan tanah secara merata dan berkeadilan melalui prinsip-prinsip dasar yang terkandung dan diamanatkannya (Anonim, 1999a)

Tanah bagi masyarakat yang sebagian besar masih bergantung di sektor pertanian memiliki makna yang multi dimensional. Pertama, dari sisi ekonomi, tanah merupakan sarana produksi yang dapat mendatangkan kesejahteraan. Kedua, secara politis, tanah dapat menentukan posisi seseorang dalam pengambilan keputusan masyarakat. Ketiga, sebagai kapital budaya, dapat menentukan tinggi rendahnya status sosial pemiliknya. Oleh karena makna yang multidimensional tersebut, ada kecenderungan bahwa orang yang memiliki tanah akan berupaya mempertahankan tanahnya dengan cara apapun apabila hakhaknya dilanggar. Pepatah jawa yang menegaskan "sak dumuk batuk senyari bumi" atau apapun resiko yang akan diterima tetap akan dibela sampai titik darah penghabisan merupakan cerminan bagaimana gigihnya orang membela tanah miliknya. Maka tidak mengherankan apabila setiap penyelesaian konflik pertanahan cenderung menjadi rumit bahkan sering mengundang berbagai bentuk tindak kekerasan massal (Anonim, 1999b).

Kegiatan pembangunan yang terus meningkat akan makin banyak memerlukan tanah ditengah-tengah keterbatasan persediaan akan sumber daya tanah itu sendiri. Hal ini akan berakibat pada terjadinya persaingan dalam penggunaan tanah, semakin menurunnya kemampuan daya tampung suatu wilayah dan mendorong terjadinya penggunaan tanah tanpa memperhatikan kondisi kemampuan tanah serta kelestarian lingkungannya. Di lain pihak, banyak tanah-tanah yang belum diusahakan atau dimanfaatkan sesuai dengan peruntukkannya, dan sebaliknya, banyak terjadi penggunaan tanah yang tidak sesuai dengan potensi fisik tanah dan arahan yang telah digariskan dalam rencana tata ruangnya. Untuk itu perlu ditumbuhkan tentang arti penting penggunaan tanah secara terencana, agar diperoleh manfaat yang optimal, serasi, seimbang dan lestari. Berbagai indikasi adanya masalah pemanfaatan tanah yang merupakan pengaruh dari persaingan dalam penggunaan tanah, antara lain : (1). Semakin berkurangnya luas tanah pertanian subur untuk kebutuhan sektor lainnya, (2). Terjadinya benturan kepentingan berbagai sektor pembangunan dalam pemanfaatan tanah, (3). Menurunnya kualitas tanah dan lingkungan, serta meluasnya tanah kritis akibat pemanfaatan tanah yang tidak sesuai dengan potensinya, (4). Pemanfaatan tanah kurang optimal sesuai dengan yang telah diperuntukkan atau direncanakan. Dengan demikian pengaturan mengenai tingkat dan berbagai kepentingan yang harus mendapatkan prioritas dalam pemanfaatan tanah dirasakan sangat penting (Salindeho, 1993).

Peraturan tentang pemanfaatan tanah ini sesuai dengan yang diamanatkan dalam pasal 15 UUPA, bahwa memelihara termasuk menambah kesuburan tanah serta mencegah kerusakannya adalah kewajiban setiap orang, badan hukum atau instansi yang mempunyai hubungan hukum dengan tanah, dengan memperhatikan pihak-pihak ekonomi lemah (Soetiknyo, 1990).

Kebijakan pertanahan secara lebih lanjut dalam Undang-undang Penataan Ruang No. 26 tahun 2007, juga ditegaskan bahwa ruang daratan adalah bagian dari ruang secara keseluruhan, dimana tanah merupakan subsistem dari ruang adalah merupakan bagian dominan dari ruang daratan, yang pengaturannya diwujudkan dalam bentuk pengelolaan tata guna tanah atau Penatagunaan Tanah. Dengan demikian, kegiatan penatagunaan tanah harus mampu mendukung pencapaian tujuan-tujuan pemanfaatan tanah 


\section{R. Kunto Adi : Penatagunaan tanah berbasis masyarakat dalam menunjang ...}

secara optimal, serasi, seimbang dan lestari. Dalam kaitan ini, maka pengaturan penguasaan, penggunaan dan pemanfaatan tanah merupakan faktor yang sangat menentukan bagi perumusan substansi penatagunaan tanah tersebut. Dalam pelaksanaannya, penatagunaan tanah harus dilaksanakan berdasar asas-asas penataan ruang yang terkait dengan aspek pertanahan, yaitu pemanfaatan tanah bagi semua kepentingan secara terpadu, berdaya guna, berhasil guna, serasi, selaras, seimbangn dan berkelanjutan. Disamping itu, juga berpegang pada asas keterbukaan, persamaan, keadilan, dan perlindungan hukum serta dengan mempertimbangkan penguasaan dan pemilikan tanah, fungsi sosial hak atas tanah, serta perlindungan terhadap golongan ekonomi lemah (Muchsin dan Koeswahyono, 2008).

\section{PENATAGUNAAN TANAH}

Penatagunaan tanah merupakan salah satu upaya dalam rangka Reforma Agraria (Agrarian Reform) atau Pembaruan Agraria, yang dapat diartikan secara sempit sebagai Land Reform, yang dalam arti sempit berarti redistribusi tanah, sedangkan dalam arti luas berarti pembaruan dalam struktur penguasaan, struktur produksi dan struktur pelayanan pendukung. Sedangkan arti Agrarian Reform dalam arti luas, merupakan upaya perubahan atau perombakan sosial yang dilakukan secara sadar, guna mentransformasikan struktur agraria ke arah sistem agraria yang lebih sehat dan merata bagi pengembangan pertanian dan kesejahteraan masyarakat desa (Wiradi, et al, 2001).

Apabila dikaitkan dengan Land Reform, minimal harus dengan upaya redistribusi tanah dan pengaturan bagi hasil, atau intinya adalah pemerataan tanah sebagai sumber daya pertanian, terutama dalam pengembangan agribisnis. Oleh karena tanah merupakan faktor produksi yang terbatas, tidak tergantikan, tidak bisa dibuat dan merupakan pemberian alam. Oleh karena itu tidak ada alasan sama sekali bagi dibolehkannya monopoli tanah atau pertuanan tanah. Tanpa adanya land reform akan berakibat :

1. Tidak ada kekuatan daya beli yang artinya tidak adanya kekuatan pasar, dan tanpa kekuatan pasar produksi tidak aka berkembang, karena pada dasarnya land reform menciptakan pasar atau daya beli.

2. Petani tanpa asset tanah, sama artinya dengan petani miskin yang tidak mampu untuk menciptakan tabungan.

3. Tanpa peningkatan ekonomi petani, maka pajak pertanian akan tetap minim.

4. Tidak akan terjadi diferensiasi yang meluas dari pembagian kerja di pedesaan yang tumbuh karena kebutuhan pedesaan itu sendiri.

5. Tidak akan terjadi investasi di dalam pertanian oleh petani sendiri, malahan akan terjadi disinvestasi, karena lama kelamaan banyak petani kehilangan tanah dan kemiskinan meluas.

6. Tanah akhirnya hanya menjadi obyek spekulasi, karena tidak mampu digunakan secara produktif oleh petani, melainkan dijarah oleh kelas-kelas di kota bagi kepentingan spekulasi dan investasi non produktif.

(Wiradi, 2001).

Penatagunaan tanah atau pola pengelolaan tata guna tanah yang meliputi penguasaan, penggunaan, dan pemanfaatan tanah melalui pengaturan kelembagaan yang terkait dengan pemanfaatan tanah sebagai satu kesatuan sistem untuk kepentingan masyarakat secara adil. Penatagunaan tanah mencakup 4 (empat) unsur esensial, yaitu : (1). Adanya serangkaian kegiatan / aktivitas, yaitu pengumpulan data lapangan tentang penggunaan, penguasaan, kemampuan fisik, pembuatan rencana/pola penggunaan tanah, penguasaan dan keterpaduan yang dilakukan secara integral dan koordinasi antar sektoral, (2). Dilakukan secara berencana, harus sesuai dengan prinsip lestari, optimal, serasi dan seimbang, (3). Adanya tujuan yang hendak dicapai, yaitu sejalan dengan tujuan pembangunan untuk sebesar - besar kemakmuran rakyat, dan (4). Harus memperhatikan daftar skala prioritas dalam penggunaan tanah. Sedangkan tujuan penatagunaan tanah adalah : (1). Mengatur penguasaan, penggunaan dan pemanfaatan tanah bagi berbagai kebutuhan kegiatan pembangunan yang sesuai dengan Rencana Tata Ruang Wilayah, (2). Mewujudkan penguasaan, penggunaan dan pemanfaatan tanah agar sesuai dengan arahan fungsi 


\section{R. Kunto Adi : Penatagunaan tanah berbasis masyarakat dalam menunjang ...}

kawasan dalam Rencana Tata Ruang Wilayah, (3). Mewujudkan tertib pertanahan yang meliputi penguasaan, penggunaan dan pemanfaatan tanah termasuk pemeliharaan tanah serta pengendalian pemanfaatan tanah, dan (4). Menjamin kepastian hukum untuk menguasai, menggunakan dan memanfaatkan tanah bagi masyarakat yang mempunyai hubungan hukum dengan tanah sesuai dengan Rencana Tata Ruang Wilayah yang telah ditetapkan (Muchsin dan Koeswahyono, 2008).

Sejalan dengan Otonomi Daerah, daerah mempunyai kewenangan yang cukup luas untuk membuat perencanaan pembangunan di daerahnya masing-masing, termasuk dalam penetapan kebijakan penatagunaan tanah. Hal ini berarti daerah harus lebih mampu menetapkan skala prioritas yang tepat dalam kegiatan penatagunaan tanah dengan tetap memperhatikan aspek ekonomi, sosial, dan kelestarian lingkungan hidup agar pembangunan dapat berjalan secara berkesinambungan. Pendekatan pembangunan daerah melihat pemanfaatan ruang serta interaksi berbagai kegiatan di dalam ruang wilayah. Jadi dalam hal ini kita melihat perbedaan fungsi ruang yang satu dengan ruang yang lainnya dan bagaimana ruang tersebut saling berinteraksi untuk diarahkan pada tercapainya kehidupan yang efisien dan nyaman. Perbedaan fungsi tersebut karena perbedaan lokasi, potensi dan aktivitas utama di masing-masing ruang dimana perbedaan tersebut harus diarahkan untuk bersinergi agar saling mendukung menciptakan pertumbuhan yang serasi dan seimbang (Tarigan, 2002).

\section{SISTEM DAN USAHA AGRIBISNIS}

Agribisnis dalam arti luas mencakup semua kegiatan mulai dari pengadaan sarana produksi pertanian (farm supplies) sampai dengan tata niaga produk pertanian yang dihasilkan usahatani atau hasil olahannya. Sistem agribisnis adalah suatu kesatuan atau sistem dari berbagai kegiatan usaha yang meliputi salah satu atau keseluruhan dari mata rantai produksi, pengolahan hasil dan pemasaran yang ada hubungannya dengan pertanian dalam arti luas. Pertanian dalam arti luas adalah kegiatan usaha yang menunjang kegiatan pertanian dan kegiatan usaha yang ditunjang oleh kegiatan pertanian (Firdaus, 2008).
Kondisi agribisnis di Indonesia masih diwarnai oleh keterbatasan aksesibilitas petani terhadap tanah, aksesibilitas terhadap pasar yang disebabkan oleh kecilnya skala usaha, belum efisiennya lembaga pemasaran serta iklim investasi dan permodalan yang belum kondusif bagi bisnis di bidang pertanian. Sementara itu kelembagaan petani di pedesaan masih belum mencitrakan suatu kelembagaan komersial yang berorientasikan bisnis (Baharsjah, 1997).

Dalam pengembangan agribisnis di Indonesia dihadapkan pada permasalahan utama adalah ketersediaan lahan pertanian yang semakin berkurang, apabila tersediapun selama ini masih belum dimanfaatkan secara optimal guna mendukung pembangunan pertanian. Selama ini, masalah yang muncul dalam penggunaan tanah dalam upaya pengembangan agribisnis, antara lain :

(1). Rendahnya akses masyarakat, terutama petani, terhadap tanah, yang disebabkan luas lahan pertanian yang semakin sempit, yang disebabkan banyaknya alih fungsi lahan pertanian produktif ke penggunaan non pertanian, terutama untuk penggunaan pabrik-pabrik (industri), jasa dan perumahan; kesuburan tanah yang semakin berkurang, karena adanya degradasi lahan secara terus menerus; kurang terjaminnya status hak atas tanah; tanah menjadi obyek spekulasi, yang menyebabkan banyaknya jual beli tanah; pembagian warisan yang menyebabkan pemecahan tanah, dan lain-lain.

(2). Rendahnya partisipasi dari masyarakat, tidak hanya dalam proses perencanaan pengaturan pemilikan, penguasaan dan penggunaan tanah, pemanfaatan tanah, tetapi juga sampai pada tahap pengendalian atau pengawasan terhadap pemilikan, penguasaan dan penggunaan tanah. Terkait dengan partisipasi masyarakat, selama ini yang terjadi di sebagian besar daerah adalah kurang dilibatkan secara aktif masyarakat dalam pengambilan keputusan kebijakan yang ditetapkan oleh Pemerintah Daerah, termasuk dalam pengelolaan sumber daya tanah. Pelibatan secara aktif tersebut harus berorientasi pada kemandirian masyarakat, sehingga perlu pendekatan pemberdayaan masyarakat dalam pengelolaan tanah 


\section{R. Kunto Adi : Penatagunaan tanah berbasis masyarakat dalam menunjang ...}

secara optimal, yang diharapkan akan sangat mendukung pengembangan agribisnis.

Berkaitan dengan masalah-masalah diatas maka perlu diuraikan mengenai Penatagunaan Tanah Berbasis Masyarakat dalam mendukung pengembangan agribisnis, sehingga diharapkan dapat memberikan manfaat yaitu untuk membantu Pemerintah Daerah dalam menentukan Konsep Penatagunaan Tanah Berbasis Masyarakat dalam pengembangan Agribisnis secara integratif dan berorientasi pada partisipasi masyarakat.

\section{PENATAGUNAAN TANAH BERBASIS MASYARAKAT}

Penatagunaan tanah merupakan suatu persoalan yang mendasar, terutatama terkait dengan upaya Pemerintah Pusat dan Pemerintah Daerah dalam penyediaan tanah bagi kepentingan pembangunan. Dalam kegiatan pembangunan pusat dan daerah perlu melibatkan masyarakat dalam pengambilan kebijakan pembangunan secara integratif, termasuk juga dalam proses penatagunaan tanah, dari mulai perencanaan, pelaksanaan dan pengawasan. Pemberdayaan (empowerment) memiliki dua makna pokok, yaitu (1). Meningkatkan kemampuan masyarakat (to give ability or enable) melalui pelaksanaan berbagai kebijakan dan program pembangunan yang mencakup seluruh aspek kehidupan masyarakat, agar kondisi kehidupan masyarakat mencapai tingkat kemampuan yang diharapkan, dan (2). Memberi wewenang secara proporsional kepada masyarakat (to give power or authority to) untuk pengambilan keputusan dalam rangka membangun diri dan lingkungannya secara mandiri. Melalui pemberian wewenang akan mampu mendorong inisiatif dan kemandirian masyarakat. Dari dua makna tersebut, dapat diartikan pemberdayaan masyarakat merupakan upaya untuk memampukan dan memandirikan masyarakat.

$$
\text { Dalam rangka meningkatkan }
$$

kemampuan masyarakat, dalam hal ini pemerintah memfasilitasi masyarakat dalam mengakses berbagai sumber daya pembangunan, yaitu (a). Akses terhadap sumber daya alam, (b). Akses terhadap sumber pembiayaan, (c). Akses terhadap teknologi, yaitu teknik pengelolaan usaha yang lebih efisien dan efektif, termasuk penyediaan prasarana dan sarana produksi dan peningkatan ketrampilan berusaha, dan (d). Akses terhadap informasi pasar dan pemasaran hasil usaha. Sedangkan dalam rangka meningkatkan kemandirian masyarakat, pemerintah berkewajiban untuk memberikan wewenang kepada masyarakat untuk pengambilan keputusan dalam rangka membangun diri dan lingkungannya secara mandiri. Proses pengambilan keputusan pada tingkat masyarakat dapat melembaga di dalam berbagai institusi masyarakat yang ada, baik melalui kelompok-kelompok swadaya yang diinisiatifi masyarakat maupun lembaga yang diinisiatifi pemerintah (Anonim, 2000).

Pendekatan penatagunaan tanah dalam artikel ini menggunakan 2 (dua) model penatagunaan tanah berbasis masyarakat, yaitu pendekatan ekonomi dan sosiologis, yang berarti pendekatan yang tidak hanya berorientasi pada peningkatan akses petani terhadap sumber daya ekonomi (tanah), sehingga memberikan keuntungan ekonomi bagi petani, tetapi juga keuntungan sosial, dilihat dari akses partisipasi masyarakat terhadap kebijakan penatagunaan tanah bagi kepentingan pembangunan. Pendekatan utama yang digunakan adalah pendekatan pemberdayaan masyarakat.

Paradigma pembangunan berbasis masyarakat sebagai sumber daya dalam pengelolaan pembangunan dikenal sebagai community management. Community management ini merupakan suatu sosok manajemen pembangunan yang mencoba menjawab tantangan pembangunan, yaitu kemiskinan, memburuknya lingkungan hidup, dan kurangnya partisipasi masyarakat di dalam proses pembangunan yang menyangkut diri mereka. Paradigma ini merupakan mekanisme perencanaan people centered department yang menekankan pada teknologi social learning dan strategi perumusan program yang bertujuan untuk mengaktualisasikan diri mereka (Tjokrowinoto, 1999).

Ciri-ciri pendekatan community management tersebut jelas berbeda dari ciri-ciri pendekatan yang mengacu pada productioncentered development, seperti misalnya 


\section{R. Kunto Adi : Penatagunaan tanah berbasis masyarakat dalam menunjang ...}

pendekatan top-down, blue print sebagaimana dapat dilihat dalam tabel di bawah ini.

Apa yang dapat disimpulkan dari sifat-sifat diatas adalah adanya kecenderungan pendekatan top-down, blue print untuk menciptakan ketergantungan (dependency creating), dan kecenderungan pendekatan community management untuk mengaktualisasikan potensi masyarakat (empowering). Program-program yang lahir dari manajemen pembangunan top-down, blue print cenderung bersifat dependency creating, dan program yang lahir dari manajemen pembangunan yang berbasis masyarakat cenderung bersifat empowering. Perbedaan kedua program pembangunan itu dapat dilihat dalam tabel di bawah ini.

Tabel 1. Ciri-ciri Pendekatan Pengelolaan Sumber Daya Lokal dan Pendekatan Top-Down

\begin{tabular}{|c|c|c|}
\hline Hal & Top-Down Print & Pengelolaan Sumber Daya Lokal \\
\hline Ciri-ciri & $\begin{array}{l}\text { Pemerintah pusat menyediakan } \\
\text { semu sumber }\end{array}$ & $\begin{array}{l}\text { Sumber dari pusat merupakan pemicu } \\
\text { mobilisasi sumber setempat yang } \\
\text { dilakukan masyarakat sendiri }\end{array}$ \\
\hline Penerapan & $\begin{array}{l}\text { Apabila sumber dari pusat } \\
\text { berlimpah; apabila sumber lokal } \\
\text { yang akan terpakai tidak ada lagi }\end{array}$ & $\begin{array}{l}\text { Sumber pusat tidak mencukupi, sumber } \\
\text { lokal belum dimanfaatkan sepenuhnya, } \\
\text { apabila diinginkan pembangunan } \\
\text { setempat yang mandiri }\end{array}$ \\
\hline Keuntungan & Cepat dan mudah & Pemanfaatan sumber lokal sepenuhnya \\
\hline Kerugian & $\begin{array}{l}\text { Menciptakan ketergantungan, } \\
\text { pembangunan akan terhenti kalau } \\
\text { subsidi dihentikan }\end{array}$ & $\begin{array}{l}\text { Sulit dimulai, lamban dan sulit } \\
\text { pengelolaannya }\end{array}$ \\
\hline Prioritas & $\begin{array}{l}\text { Infrastruktur pelayanan dari pusat } \\
\text {; pemerintah pusat menggali } \\
\text { sumber-sumber potensial }\end{array}$ & $\begin{array}{l}\text { Masyarakat setempat } \\
\text { meminimalisasikan sumber-sumber }\end{array}$ \\
\hline
\end{tabular}

Sumber : Tjokrowinoto (1999)

Tabel 2. Program Pembangunan yang Empowering dan Dependency Creating

\begin{tabular}{|c|c|c|}
\hline & Empowering & Dependency Creating \\
\hline Prakarsa & Di desa & Di Ibukota \\
\hline $\begin{array}{l}\text { Dimulai dengan proses desain } \\
\text { program }\end{array}$ & Pemecahan masalah & $\begin{array}{l}\text { Rencana formal statis, didominasi } \\
\text { pakar }\end{array}$ \\
\hline Teknologi & Asli-ilmiah & Ilmiah \\
\hline Sumber utama & Rakyat sumber lokal & Dana teknisi pusat \\
\hline Kesalahan & Diterima (embraced) & Diabaikan dan dilalaikan \\
\hline Organisasi pendukung & Dibina dari bawah & Dibina dari atas \\
\hline Pertumbuhan organik & Tahap demi tahap & Cepat mekanistik \\
\hline Pembinaan personil & $\begin{array}{l}\text { Berkesinambungan } \\
\text { berdasar pengalaman } \\
\text { lapangan belajar dari } \\
\text { kegiatan lapangan }\end{array}$ & $\begin{array}{l}\text { Prajabatan pendidikan formal } \\
\text { didaktik }\end{array}$ \\
\hline Diorganisir oleh & Tim interdisipliner & Technical specialists \\
\hline Evaluasi & $\begin{array}{l}\text { Oleh diri sendiri } \\
\text { berkesinambungan process } \\
\text { oriented }\end{array}$ & $\begin{array}{l}\text { Eksternal selang-seling impact } \\
\text { oriented }\end{array}$ \\
\hline Kepemimpinan & $\begin{array}{l}\text { Kuat berkelanjutan } \\
\text { individual }\end{array}$ & Terbatas berubah-ubah positional \\
\hline Analisis sosial & $\begin{array}{l}\text { Untuk definisi masalah dan } \\
\text { perbaikan program }\end{array}$ & $\begin{array}{l}\text { Untuk membenarkan rencana dan } \\
\text { memenuhi persyaratan evaluasi }\end{array}$ \\
\hline Fokus manajemen & $\begin{array}{l}\text { Kelangsungan } \\
\text { berfungsinya sistem dan } \\
\text { kelembagaan }\end{array}$ & $\begin{array}{l}\text { Selesainya proyek pada waktu } \\
\text { yang ditentukan }\end{array}$ \\
\hline
\end{tabular}

Sumber : Tjokrowinoto (1999). 


\section{PRASYARAT TERLAKSANANYA PENATAGUNAAN TANAH BERBASIS MASYARAKAT}

Prasyarat pelaksanaan penatagunaan tanah secara umum disebutkan bahwa untuk terlaksananya penatagunaan tanah berbasis masyarakat diperlukan: (a) Kemauan politik dan pemerintah; (b) Data yang lengkap dan teliti mengenai keagrariaan; (c) Organisasi masyarakat/tani yang kuat; dan (d) Elit penguasa/birokrasi yang terpisah dari elit bisnis. Keempat hal di atas merupakan syarat keharusan bagi terlaksananya penatagunaan tanah dan ditambah dengan adanya suatu lembaga khusus yang menangani masalah ini. Selain hal-hal di atas secara teknis, pelaksanaan penatagunaan tanah perlu didukung oleh : (a) Adanya tenaga pelaksana yang jujur, (b) Tersedianya data/peta penguasaan dan pemilikan lahan yang lengkap, serta (c) Dukungan dana yang terus menerus. Penatagunaan tanah dari awal perlu juga menentukan pola mana yang akan dilaksanakan, apakah Collectivist atau Redistributive (Wiradi, 2001). Pada yang pertama mengambil dari yang kecil untuk diberikan kepada yang besar dan yang kedua mengambil dari yang besar untuk diberikan kepada yang kecil. Untuk Indonesia nampaknya lebih mengarah pada Redistributive, dengan penentuan luas maksimum dan minimum pemilikan lahan.

Sesuai dengan isi pasal 1 ayat 1 UndangUndang No. 56 tahun 1960 tentang penetapan Luas Tanah Pertanian, disebutkan bahwa seseorang atau keluarga diperbolehkan menguasai lahan sawah maksimum 5-15 hektar tergantung kepadatan penduduk dan lahan kering 6-20 hektar. Sementara itu pasal 8 pada Undang Undang yang sama diatur agar pemerintah mengadakan usaha-usaha agar setiap petani sekeluarga memiliki lahan pertanian minimum dua hektar. Dalam kondisi saat ini, batasan ini perlu ditinjau kembali, mengingat sulitnya memenuhi batasan tersebut dan semakin tingginya kepadatan penduduk. Persoalannya sekarang berapa batas minimum dan maksimum yang diizinkan di suatu wilayah, dan apa patokan yang digunakan. Nasoetion dan Yudohusodo dalam Jamal (2000) menyatakan bahwa economic of scale pada usaha tani padi baru akan terjadi manakala dilakukan pada lahan seluas lebih dari 1 (satu) hektar, sehingga keduanya sepakat merekomendasikan agar luas penguasaan lahan oleh petani per rumah tangga minimal 1 (satu) hektar.

Dari berbagai hambatan seperti yang dipaparkan pada bagian terdahulu, terlihat bahwa persoalan mendasar berkaitan dengan pelaksanaan penatagunaan tanah adalah ketersediaan data dan informasi yang akurat tentang lahan dan kependudukan. Informasi tentang lahan tersebut terutama berkaitan dengan struktur penguasaan, pemilikan dan pengusahaan lahan serta berbagai kelembagaan yang terkait dengan keberadaan lahan tersebut. Menurut Sandy dalam Silalahi (2000), data dasar tentang penguasaan/pemilikan dan pengusahaan lahan serta kelembagaan yang terkait dengan keberadaan lahan akan dengan mudah dapat menuntun berbagai upaya perbaikan yang akan dilakukan. Selain itu dari peta lahan yang komprehensif dapat ditaksir tingkat kesejahteraan masyarakat dan upayaupaya yang mungkin dapat dilakukan dalam memperbaiki kesejahteraan masyarakat tersebut.

Pelaksanaan Sensus Pertanian sebenarnya dapat dijadikan sebagai upaya awal untuk mendapatkan data yang akurat tentang struktur penguasaan/pemilikan lahan serta dinamika penguasaan/pemilikannya. Dengan berbagai keterbatasan yang dimiliki Badan Pertanahan Nasional (BPN) menyebabkan sulit bagi lembaga tersebut untuk menghasilkan sesuatu yang komprehensif dan lengkap, tanpa adanya bantuan dan lembaga/instansi lain yang mempunyai perhatian terhadap masalah ini. Oleh karena itu berbagai studi akan sangat membantu BPS dalam perencanaan dan pelaksanaan Sensus Pertanian. Hal-hal sederhana seperti batasan tentang pemilikan, penguasaan dan lainnya yang sangat beragam, merupakan hal-hal yang perlu dilihat pada studi pendasaran selain dinamika dalam penguasaan/pemilikan lahan serta kelembagaan yang mengatur penguasaan lahan di pedesaan. Berkaitan dengan informasi kependudukan, adanya upaya untuk membuat data secara terintegrasi dalam level nasional. akan sangat banyak membantu upaya perbaikan akses masyarakat terhadap lahan. Pada masa yang akan datang data tentang lahan dan yang berwenang mengelola upaya khusus reformasi 


\section{R. Kunto Adi : Penatagunaan tanah berbasis masyarakat dalam menunjang ...}

agraria sebaiknya ditangani oleh suatu badan khusus, yang tidak terlalu banyak dibebani tugas administratif seperti BPN. Reformasi dalam peraturan/undang-undang yang terkait dengan lahan perlu diawali dengan UndangUndang Pokok Agraria (UUPA). Hal-hal yang mengarah pada dominasi negara terhadap pemanfaatan lahan perlu direformasi. Selain itu, berbagai Undang-Undang dan produk hukum lainnya perlu juga direformasi, sehingga kesan bahwa semua lahan di negara ini sudah dikapling oleh kepentingan sektoral tidak terlalu menonjol seperti selama ini. Pada tingkat perencana di pusat dan di daerah perlu melibatkan masyarakat lokal dalam perencanaan pemanfaatan lahan untuk kepentingan kehutanan, pertambangan, pertanian dan lainnya, sehingga masyarakat lokal tidak hanya menjadi penonton dan membiarkan lingkungannya rusak serta hilangnya beberapa kearifan lokal dalam pemanfaatan sumber daya. Pelibatan masyarakat dalam penatagunaan tanah tersebut mulai pada tahap perencanaan penggunaan tanah, penggunaan tanah, maupun tahap pengendalian penggunaan tanah.

Hal lain yang tak kalah pentingnya dalam penatagunaan tanah adalah sikap pemerintah tentang tanah adat atau tanah ulayat. Walaupun dalam UUPA keberadaan tanah adat diakui, namun dalam kenyataannya masyarakat adat sering diabaikan dalam pemanfaatan lahan yang ada di wilayahnya. Persoalan dengan lahan adat ini seringkali berkaitan dengan sulitnya menentukan batasbatas lahan mereka. Namun dari beberapa penelitian terlihat bahwa hal itu bukanlah masalah utama dalam pemanfaatan lahan masyarakat adat. Menurut Atok (2000), masyarakat adat dapat dengan mudah mengenali batas-batas lahan hak ulayatnya, masalahnya sekarang seberapa jauh upayaupaya semacam ini dapat terintegrasi dengan berbagai aturan dan undang-undang yang ada, sehingga masyarakat adat punya bargaining position yang kuat bila berhadapan dengan investor atau pendatang dari luar. Petani sebagai penerima lahan objek land reform dalam proses penatagunaan tanah juga perlu disiapkan, sebelum mereka menerima lahan. Diharapkan dengan demikian mereka dapat mengelola lahan tersebut secara berkelanjutan. Selain itu tata aturan dalam proses penentuan lahan objek land reform dan untuk mendapatkan lahan tersebut perlu diperjelas dan dibuat tidak terlalu rumit seperti yang selama ini ada. Sehingga jelas objek, pelaku dan tata aturan dari proses ini.

Dengan mengacu pada berbagai masalah diatas maka, penulis merumuskan beberapa tahapan dalam proses penatagunaan tanah berbasis masyarakat dalam pengembangan agribisnis, yang dilaksanakan melalui kegiatankegiatan sebagai berikut :

1. Identifikasi sektor-sektor agribisnis, stakeholders, dan pemetaan wilayahwilayah yang mempunyai komoditas agribisnis potensial untuk dikembangkan

2. Identifikasi kebutuhan dan masalah yang dihadapi selama ini dalam pengembangan agribisnis, dalam kaitannya dengan penatagunaan tanah.

3. Kajian cepat strategi penatagunaan tanah dalam pengembangan agribisnis dan penetapan faktor keberhasilan strategi

4. Penetapan model penatagunaan tanah berbasis masyarakat dalam pengembangan agribisnis, berdasarkan hasil penyusunan strategi dan penyesuaian penatagunaan tanah yang ada dengan Rencana Tata Ruang Wilayah (RTRW) yang sudah ditetapkan, dalam bentuk rekomendasi kepada Pemerintah Daerah.

5. Penetapan rencana tindak penatagunaan tanah berbasis masyarakat dalam pengembangan agribisnis, melalui integrasi model penatagunaan tanah ke dalam Rencana Pembangunan Jangka Menengah dan Jangka Panjang, serta penyesuaian penatagunaan tanah yang ada dengan Rencana Tata Ruang Wilayah (RTRW) yang sudah ditetapkan.

6. Pelaksanaan rencana tindak penatagunaan tanah berbasis masyarakat dalam pengembangan agribisnis.

7. Monitoring dan Evaluasi, terkait dengan efektivitas pelaksanaan model dan rencana tindak penatagunaan tanah dan menyusun rekomendasi perbaikan.

\section{HAMBATAN DALAM PELAKSANAAN PENATAGUNAAN TANAH BERBASIS MASYARAKAT}

Pada tahap awal perencanaan pelaksanaan penatagunaan tanah berbasis masyarakat, hal 


\section{R. Kunto Adi : Penatagunaan tanah berbasis masyarakat dalam menunjang ...}

yang perlu dirumuskan dengan baik adalah apa objek yang akan ditata dan siapa pelakunya serta aturan mainnya. Objek yang akan ditata berkaitan dengan sumber daya lahan dan semua yang ada di atasnya. Pelaku adalah terdiri dari pelaksana, penerima dan yang memberi, sedangkan aturan main adalah peraturan/undang-undang dan kelembagaan yang melekat pada objek tersebut.

Pelaksanaan penatagunaan tanah pada tahap awal yang mungkin untuk dilaksanakan adalah land reform. Walaupun masih banyak perdebatan tentang hal ini, namun untuk Indonesia hal ini mungkin dan bisa dilaksanakan. Sumber objek land reform adalah tanah negara, tanah kelebihan dan batas maksimum, tanah absentee dan tanah partikelir. Beberapa hasil studi, terutama Padmo dalam Jamal (200), menyebutkan bahwa hambatan dalam penentuan objek land reform adalah kesulitan teknis dalam mengidentifikasi kelebihan bidang tanah dan maksimum pemilikan/penguasaan lahan terutama di pedesaan, serta lemahnya sistem informasi kependudukan untuk melacak tanah absentee. Pelaku dari proses penatagunaan tanah adalah petani/tuan tanah yang lahannya menjadi objek land reform, pelaksana proses land reform dan penerima objek land reform. Penentuan penerima objek landreform sama sulitnya dengan penentuan lahan yang bisa menjadi objek landreform. Pengalaman dari beberapa pelaksanaan proses ini, selain sulitnya menentukan petani yang berhak rnendapatkan lahan objek landreform dari lahan bekas perkebunan, masalah kesiapan petani juga menentukan keberhasilan program ini. Karena kurang siapnya petani penerima objek land reform, maka lahan objek landreform tidak dapat dikelola dengan baik dan pada akhirnya lahan yang ada kembali terakumulasi pada beberapa petani. Dalam pelaksanaan transmigrasi di beberapa tempat, ditemui juga tuan-tuan tanah baru dari petani yang berhasil yang membeli lahan milik petani yang gagal dan kembali ke daerah asal. Selama ini pelaksana landreform adalah Badan Pertanahan Nasional, dan ini merupakan salah satu tugasnya disamping berbagai tugas lainnya. Pasal 2 Undang-Undang Pokok Agraria menyatakan negara menguasai lahan dan berhak mengatur peruntukkan dan relasi dalam pemanfaatan lahan tersebut. Bertitik tolak dari ketentuan ini pemerintah kemudian dengan leluasa membuat berbagai peraturan dan perundangan yang mengatur pemanfaatan lahan miliknya. Setelah diberlakukannya UUPA pada tahun 1960, kemudian lahirlah berbagai Undang Undang yang mengatur pola pemanfaatan lahan untuk berbagai sektor dan bidang. Sampai tahun 1992, Undang-Undang yang diciptakan tersebut antara lain:

1. Undang-Undang No. 5 Tahun 1967 tentang Ketentuan-ketentuan Pokok Kehutanan.

2. Undang-Undang No. 11 Tahun 1967 tentang Ketentuan-ketentuan Pokok Pertambangan.

3. Undang-Undang No. 3 Tahun 1972 tentang Ketentuan-ketentuan Pokok Transmigrasi.

4. Undang-Undang No. 11 Tahun 1974 tentang Pengairan.

5. Undang-Undang No. 13 Tahun 1980 tentang Jalan.

6. Undang-Undang No. 4 Tahun 1982 tentang Ketentuan-ketentuan Pokok Pengelolaan Lingkungan Hidup.

7. Undang-Undang No. 5 Tahun 1984 tentang Perindustrian.

8. Undang-Undang No. 12 Tahun 1992 tentang Sistem Budidaya Tanaman.

9. Undang-Undang No. 26 Tahun 2007 tentang Penataan Ruang.

Selain Undang-Undang tersebut, dibuat juga berbagai peraturan lain seperti Keppres, Kepmen dan lain sebagainya yang menunjukkan dominasi pemerintah dalam pengaturan pemanfaatan lahan. Menurut Nasoetion dalam Jamal (2000) di dalam suatu negara dimana eksekutif (pemerintah) relatif lebih kuat dari yudikatif dan legislatif, hak menguasai dari negara sebagaimana yang tercantum pada pasal 2, UUPA mudah tergelincir menjadi kesewenang-wenangan pemerintah atau abuse of power yang dapat merugikan rakyat yang secara politik lemah. Untuk melakukan reformasi pertanahan berkaitan dengan tata aturan dalam pemanfaatan lahan ini diperlukan adanya komitmen pemerintah untuk melakukan berbagai perbaikan dalam penatagunaan tanah. 


\section{R. Kunto Adi : Penatagunaan tanah berbasis masyarakat dalam menunjang ...}

\section{KESIMPULAN DAN SARAN}

\section{Kesimpulan}

Dari uraian di atas terlihat bahwa pelaksanaan penatagunaan tanah berbasis masyarakat bukanlah suatu pekerjaan mudah, namun sangat perlu dilaksanakan sebagai basis upaya perbaikan akses masyarakat terhadap sumber daya produktif dalam pengembangan agribisnis. Beberapa tahapan dalam proses penatagunaan tanah berbasis masyarakat dalam pengembangan agribisnis, dapat dilaksanakan melalui kegiatan-kegiatan, yang meliputi : identifikasi sektor-sektor agribisnis, stakeholders, dan pemetaan wilayah-wilayah yang mempunyai komoditas agribisnis potensial untuk dikembangkan; identifikasi kebutuhan dan masalah yang dihadapi selama ini dalam pengembangan agribisnis, dalam kaitannya dengan penatagunaan tanah; kajian cepat strategi penatagunaan tanah dalam pengembangan agribisnis dan penetapan faktor keberhasilan strategi; penetapan model penatagunaan tanah berbasis masyarakat dalam pengembangan agribisnis, berdasarkan hasil penyusunan strategi dan penyesuaian penatagunaan tanah yang ada dengan Rencana Tata Ruang Wilayah (RTRW) yang sudah ditetapkan, dalam bentuk rekomendasi kepada Pemerintah Daerah; penetapan rencana tindak penatagunaan tanah berbasis masyarakat dalam pengembangan agribisnis, melalui integrasi model penatagunaan tanah ke dalam Rencana Pembangunan Jangka Menengah dan Jangka Panjang, serta penyesuaian penatagunaan tanah yang ada dengan Rencana Tata Ruang Wilayah (RTRW) yang sudah ditetapkan; pelaksanaan rencana tindak penatagunaan tanah berbasis masyarakat dalam pengembangan agribisnis; dan monitoring dan Evaluasi, terkait dengan efektivitas pelaksanaan model dan rencana tindak penatagunaan tanah dan menyusun rekomendasi perbaikan.

\section{Saran}

Dalam mengimplementasikan tahapan proses penatagunaan tanah tersebut sangat diperlukan adanya Political Comitment dan pemerintah untuk melaksanakan hal ini, karena upaya ini merupakan suatu kerja besar yang butuh perencanaan yang terintegrasi dan dana besar dalam kurun waktu yang lama. Upaya ini perlu didahului dengan pendataan mengenai kondisi penguasaan dan pemilikan tanah eksisting secara komprehensif dan akurat, dan ini merupakan basis dalam perencanaan selanjutnya. Arti pentingnya penatagunaan tanah ini perlu terus disuarakan oleh berbagai pihak yang peduli tentang masalah pertanahan, sehingga pihak pengambil kebijakan menyadari hal ini. Pada tingkat legislatif upaya pembaruan hukum dan perundangan yang terkait dengan pertanahan, perlu menjadi agenda utama untuk mendukung proses penatagunaan tanah, sehingga masyarakat yang menguasai dan atau memiliki tanah mempunyai kepastian dalam pemanfaatan tanah dan dilindungi hak-hak atas tanahnya untuk berproduksi dan mencari penghidupan yang layak sebagaimana diamanatkan Undang-Undang Dasar 1945.

Pihak lain yang juga harus ikut andil adalah Perguruan Tinggi, Lembaga/Instansi Swasta dan Lembaga Swadaya Masyarakat (LSM) sebagai partner pemerintah dan sekaligus partner petani diharapkan tidak hanya melaksanakan advokasi agar petani dapat akses terhadap tanah secara lebih baik, tetapi juga dapat secara bersama menyiapkan petani yang akan menerima lahan objek land reform, sehingga mereka dapat mengelola tanah tersebut nantinya dengan baik. Pengalaman selama ini, petani yang menerima objek landreform seringkali tidak siap mengelola tanahnya, sehingga tanah yang ada kembali terakumulasi pada beberapa petani kaya.

Selain itu, dalam proses penatagunaan tanah harus dengan pendekatan community management untuk mengaktualisasikan potensi masyarakat (empowering). Program-program yang lahir dari manajemen penatagunaan tanah bersifat bottom up dan blue print yang tidak bersifat dependency creating, sehingga program yang lahir dari manajemen penatagunaan tanah berbasis masyarakat cenderung bersifat empowering, sehingga masyarakat terutama petani tidak hanya sebagai obyek, tetapi subyek, dalam implementasi proses penatagunaan tanah dalam sistem dan usaha agribisnis di Indonesia.

\section{DAFTAR PUSTAKA}

Anonim. 1999a. Reformasi Kebijakan Peraturan, Pelaksanaan dan Pelayanan 


\section{R. Kunto Adi : Penatagunaan tanah berbasis masyarakat dalam menunjang ...}

di Bidang Hukum Pertanahan. Kumpulan Makalah. Pusat Studi Hukum Agraria Universitas Trisakti. Jakarta.

b. Pengaturan Penguasaan dan Penatagunaan Tanah. Kumpulan Makalah. Deputi Bidang Pengaturan Penguasaan dan Penatagunaan Tanah Kantor Menteri Negara Agraria/BPN. Jakarta

2000. Undang-undang Agraria. Sinar Grafika. Jakarta.

Atok, K. 2000. Kondisi Agraria di Kalimantan Barat. Makalah dalam Semiloka Metoda Penelitian Agraria. PKA-LPIPB,AKATIGA Bandung dan P3KPUGM. Bogor.

Widjanarko, et al, 2012. Aspek Pertanahan Dalam Pengendalian Alih Fungsi Lahan Pertanian (Sawah). Prosiding. Seminar Nasional Multifungsi Lahan Sawah. Jakarta.

Baharsjah. 1997. Membangun Pertanian Modern Dalam Rangka Meningkatkan Daya Saing Komoditas Pertanian. Konferensi Nasional XII Perhepi. Jakarta.

Firdaus, M, 2008, Manajemen Agribisnis, Bumi Aksara, Jakarta.

Jamal, Erizal. 2000. Beberapa Permasalahan Dalam Pelaksanaan Reformasi Agraria di Indonesia. Jurnal FAE Volume 18 No. 1 dan 2, Desember. Pusat Penelitian Sosal Ekonomi Pertanian. Bogor.

Muchsin dan Koeswahyono, I. 2008. Aspek Kebijaksanaan Hukum Penatagunaan Tanah dan Penataan Ruang. Sinar Grafika. Jakarta.
Mustain. 2007. Petani vs Negara : Gerakan Sosial Petani Melawan Hegemoni Negara. Ar-Ruzz Media. Yogyakarta.

Padmo, S. 2000. Landreform dan Gerakan Protes Petani Klaten 1959-1965. Penerbit Media Pressindo bekerjasama dengan Konsorsium Pembaruan Agraria (KPA). Yogyakarta.

Salindeho, John. 1993. Masalah Tanah Dalam Pembangunan. Sinar Grafika. Jakarta.

Silalahi, S.B. 2000. Pemetaan Penguasaan, Pemilikan. dan Penggunaan Tanah thiam Rangka Reforma Agraria. Makalah dalam Semiloka Metodologi Penelitian Agraria, Tanggal 13-15 September 2000. PKA IPB Bogor.

Soetiknyo, Iman. 1990. Politik Agraria Nasional. Gadjah Mada University Press. Yogyakarta.

Tarigan, R. 2002. Perencanaan Pembangunan Wilayah Pendekatan Ekonomi dan Ruang. Departeman Pendidikan Nasioanal. Jakarta.

Tjokrowinoto, Moeljarto, 1999. Pembangunan : Dilema dan Tantangan. Tiara Wacana, Yogyakarta.

Widjanarko, Bambang, et al, 2012. Aspek Pertanahan Dalam Pengendalian Alih Fungsi Lahan Pertanian (Sawah). Prosiding. Seminar Nasional Multifungsi Lahan Sawah. Jakarta.

Wiradi, G. 2001. Prinsip-prinsip Reforma Agraria : Jalan Penghidupan dan Kemakmuran Rakyat. Lapera Pustaka Utama. Yogyakarta. 